\title{
Analysis of Publications on Acinetobacter: A Scopus Database Search Study
}

\author{
Emine Kübra Dindar Demiray ${ }^{1}$, Serpil Oğuz Mızrakçı², Sevil Alkan³ \\ Infectious Diseases and Clinical Microbiology Department, Bitlis State Hospital, Bitlis, Turkey \\ 2Infectious Diseases and Clinical Microbiology Department, Özel Lara Anadolu Hospital, Antalya, Turkey \\ ${ }^{3}$ Infectious Disease Department, Faculty of Medicine, Çanakkale Onsekiz Mart University, Canakkale,
}

Received: 2021-07-16

Accepted: 2021-09-10

This work is licensed under a

Creative Commons Attribution 4.0 International License

J Clin Med Kaz 2021; 18(5):44-48

Corresponding author:

Emine Kübra Dindar Demiray.

E-mail: e.kubradindar@hotmail.com;

ORCID: 0000-0001-6459-7182

\begin{abstract}
Aim: We aimed to review the global literature on Acinetobacter, which is a global health problem, and identify and characterize the publications to direct scientific studies.

Material and methods: We conducted a bibliometric analysis by searching the Elsevier' Scopus database. This database is one of the biggest international bibliometric database. We searched original research articles from this database using the keywords "Acinetobacter" or "Acinetobacter spp." and "Article" since July 05, 2021. We carried out detailed analysis to identify the characteristics of articles by using the bibliometric data analysis technique. The articles were analyzed due to the following characteristics: the country of origin, authors' names and affiliations, year of publication, content, number of citations and impact factor.
\end{abstract}

Results: The total number of publication on Acinetobacter were 35587 and the first publication was published in the year 1974. 30074 of these studies were research articles. Only research articles were evaluated in our study. There was a rapid increase in the number of articles after the year 2000 and the number of articles did not decrease until 2020 over the years. There was a decrease in the number of published articles in the year 2020. The majority of the articles ( $n=26862,89.31 \%)$ were written in the English language. Chinese was the second most preferred language. The most scientifically productive countries on Acinetobacter literature were the United States, China and India. Ronald N Jones $(n=174)$ from the USA and Harald Seifert $(n=114)$ from Germany were the most productive authors on Acinetobacter research.

Conclusion: As a result, both the number of articles on Acinetobacter and the number of citations were quite high. Since the Acinetobacter genus is one of the most important pathogens in hospital infections, it seems that researchers will continue to work on this topic.

Key words: Acinetobacter, bibliometric analysis, Scopus

\section{Introduction}

Acinetobacter genus is Gram-negative, double or chained cocci or coccobacilli, non-spore-forming, sometimes encapsulated, aerobic, oxidase-negative, catalase-positive bacteria [1,2]. There are difficulties in treatment, especially because they have multiple antibiotic resistance and cause hospital infections, especially in intensive care units, globally. It has been shown that there are 12 different genomic types in its taxonomic classification. There are 49 species in the genus Acinetobacter. The clinically important species are A. calcoaceticus- A. baumannii (genomic strain 2), Acinetobacter nosocomial (genomic strain 13TU), Acinetobacter pittii (genomic strain 3), and $A$. calcoaceticus (genomic strain 1), which are clinically important species [2,3]. A.baumannii complex (ABC) cannot be distinguished biochemically. Acinetobacter spp. is the most common cause especially in hospitalacquired pneumonia and bloodstream infections and their antibiotic resistances rates increase over the years $(41 \%$, $36 \%$ ) [1-5].

Although Acinetobacter species are generally considered as pathogens with low virulence, that group bacteria have multiple virulence factors. It emerges as 
an opportunistic pathogen that causes nosocomial infections with severe clinical manifestations, especially in patients with underlying disease and various risk factors [6]. Factors such as prolonged use of antibiotics, prolonged hospitalization in the hospital and especially in the intensive care unit, long-term use of medical equipment such as catheters and implants, being connected to a ventilator, cardio-pulmonary disease, extensive burns, change in consciousness and immune system deficiencies are related attributable risk factors for Acinetobacter infections development. Among Acinetobacter species, A. baumannii are known as the most virulent species. Multivariate analyzes revealed that the mortality of $A$. baumannii infections is nine times higher than infections caused by other species [6,7]. $A$. baumannii is at the top of the list of 'resistant bacteria that urgently require new antibiotic discovery' due to the increasing resistance rates published by the World Health Organization in the year 2018 [8]. Due to the antimicrobial resistance problem, studies to elucidate the virulence factors and antibiotic resistance mechanisms of $A$. baumannii should continue without slowing down in order to treat Acinetobacter infections. It should not be forgotten that researches on the inhibition of virulence factors with different methods, especially molecular methods, new applications that can be an alternative to antibiotic treatment, researches to be carried out for the development of efflux pump inhibitors and antibiofilm agents are very valuable in terms of the control of infections and public health worldwide [9].

We aimed to review the world literature on Acinetobacter, which is a global health problem, and identify and characterize the publications to direct scientific studies. To our knowledge, our study is the first bibliometric research in the field of Acinetobacter by using the Scopus database.

\section{Material and methods Research model}

In this study, bibliometric analysis method was used as a research model, which is one of the qualitative research method [10]. With this method, studies on a subject can be analyzed mathematically on the axis of various research parameters, including publication years, general characteristics, authors and institutions, keywords, funding institutions, citations, methods and samples [10].

The data of the study were obtained using the Elsevier Scopus bibliometric database, which is one of the main the international databases. This database, providing access to articles and references contained in these articles, allows it to search both forward and backward in time [10]. We searched original research articles from this database using the keywords "Acinetobacter" or "Acinetobacter spp." and "Article" since July 05, 2021. Duplications were included in the study only once. The obtained data were analyzed in the Excel file created by the researcher.

Çanakkale Onsekiz Mart University's online library and digital resources were used to access information.

\section{Data analysis}

We carried out detailed analysis to identify the characteristics of articles by using the bibliometric data analysis technique. The articles were analyzed due to the following characteristics: the country of origin, authors' names and affiliations, year of publication, content, number of citations and impact factor. Also statistical analyzes (frequency and percentage) were performed to analyse the publications by using Statistical Package for the Social Sciences (SPSS) for Windows Version 23.0 software
(SPSS Inc., Chicago, IL, USA). Data were reported as mean \pm standard deviation values, number and percentage. Descriptive statistics were used in the statistical evaluation.

\section{Ethics committee}

The study complied with the Helsinki Declaration, which was revised in 2013. Ethics committee approval is not required as there is no human or animal research.

\section{Results}

It was determined that there were 35587 publications on Acinetobacter topic and the first publication was published in the year 1974. 30074 of these studies were research articles. Only research articles were included to our study.

The greatest number of articles published in the last 20 years period from 2000 to 2020 and the number of articles did not decrease since 2020. In 2020, there was a decrease in the number of published articles (Figure 1).

Figure 1 - Number of published articles by years.

Documents by year

3500

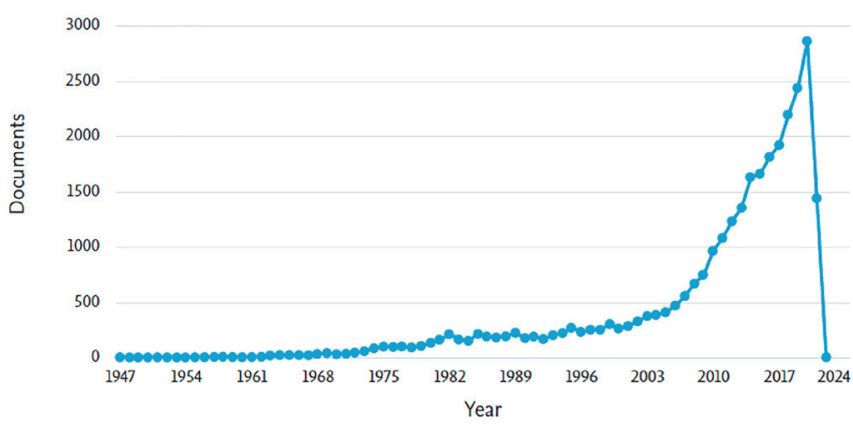

The most scientifically productive countries on Acinetobacter literature were the United States (USA), China and India. Turkey was in 9th place. The countrywide contribution of the articles is shown in Table 1.

\begin{tabular}{|c|c|c|}
\hline Table 1 & $\begin{array}{l}\text { The countrywide cont } \\
(n=30074) .\end{array}$ & ution of the articles \\
\hline Country & Number of publications & $\begin{array}{l}\text { Percentage by total } \\
\text { number of publications }\end{array}$ \\
\hline USA & 5049 & 16.78 \\
\hline China & 4559 & 15.15 \\
\hline India & 2218 & 7.37 \\
\hline United Kingdom & 1529 & 5.08 \\
\hline Germany & 1410 & 4.68 \\
\hline France & 1306 & 4.34 \\
\hline Japan & 1236 & 4.10 \\
\hline Spain & 1060 & 3.52 \\
\hline Turkey & 1034 & 3.43 \\
\hline South Korea & 985 & 3.27 \\
\hline
\end{tabular}

The majority of the articles ( $n=26862,89.31 \%$ ) were written in English language. Chinese was the second most preferred language. $12503(41.57 \%)$ of the articles were published in open access (AE) (Open Access) journals. Ranking of institutions according to the number of contributions to research given in Table 2. The institution with the highest number of contributors is Ministry of Education China $(n=363)$. China-based institutions were in the first two places among the institutions with the highest number of publications. 
Table 2

The list of top 15 institutions contributing the Acinetobacter literature $(n=30074)$.

\begin{tabular}{|l|l|l|}
\hline Institution & $\mathrm{n}$ & $\%$ \\
\hline Ministry of Education China & 363 & 1.20 \\
\hline Chinese Academy of Sciences & 283 & 0.94 \\
\hline Inserm & 179 & 0.59 \\
\hline Zhejiang University & 178 & 0.59 \\
\hline Tel Aviv University & 177 & 0.58 \\
\hline Mahidol University & 175 & 0.58 \\
\hline Hospital Clinic Barcelona & 175 & 0.58 \\
\hline Universidade de Sao Paulo - USP & 168 & 0.55 \\
\hline National Taiwan University Hospital & 168 & 0.55 \\
\hline $\begin{array}{l}\text { CNRS Centre National de la Recherche } \\
\text { Scientifique }\end{array}$ & 165 & 0.54 \\
\hline Monash University & 159 & 0.52 \\
\hline Tehran University of Medical Sciences & 151 & 0.50 \\
\hline Russian Academy of Sciences & 150 & 0.49 \\
\hline National Yang-Ming University Taiwan & 145 & 0.48 \\
\hline The University of Queensland & 141 & 0.46 \\
\hline & & \\
\hline
\end{tabular}

Figure 2 - Number publications according to journals contributing the most to the related literature on Acinetobacter.

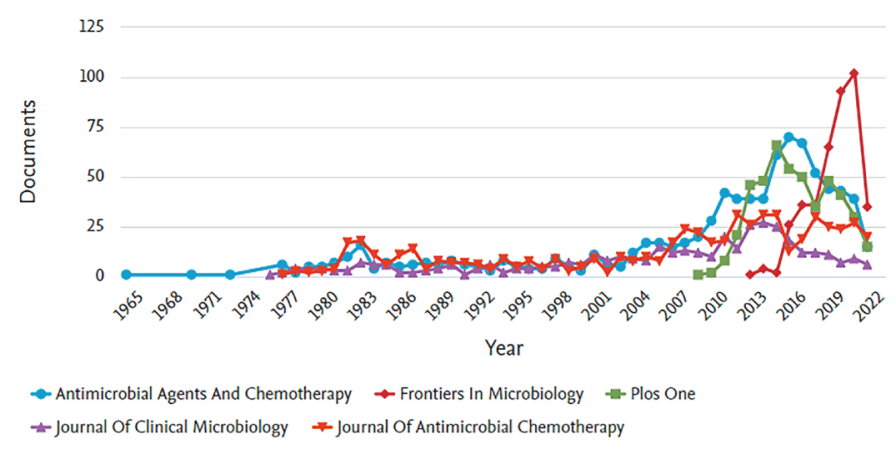

The List of Top 10 Journals Contributing the Acinetobacter Literature $(n=30074)$.

\begin{tabular}{|l|l|l|l|l|}
\hline Journals & $\mathrm{n}$ & $\%$ & $\begin{array}{l}\text { CiteScore } \\
2020\end{array}$ & $\begin{array}{l}\text { SCImago } \\
\text { Journal Rank }\end{array}$ \\
\hline $\begin{array}{l}\text { Antimicrobial Agents And } \\
\text { Chemotherapy }\end{array}$ & 874 & 2.90 & 9.1 & 2.070 \\
\hline $\begin{array}{l}\text { Journal of Antimicrobial } \\
\text { Chemotherapy }\end{array}$ & 541 & 1.79 & 9.1 & 2.124 \\
\hline Plos One & 465 & 1.54 & 5.3 & 0.990 \\
\hline Frontiers In Microbiology & 400 & 1.33 & 7.3 & 1.701 \\
\hline $\begin{array}{l}\text { Journal of Clinical } \\
\text { Microbiology }\end{array}$ & 396 & 1.31 & 9.4 & 2.349 \\
\hline $\begin{array}{l}\text { International Journal of } \\
\text { Antimicrobial Agents }\end{array}$ & 323 & 1.07 & 12 & 1.454 \\
\hline $\begin{array}{l}\text { Diagnostic Microbiology } \\
\text { And Infectious Disease }\end{array}$ & 306 & 1.01 & 4.6 & 1.027 \\
\hline Chemotherapy & 282 & 0.93 & 3.7 & 0.539 \\
\hline $\begin{array}{l}\text { American Journal Of } \\
\text { Infection Control }\end{array}$ & 279 & 0.92 & 4.2 & 1.004 \\
\hline $\begin{array}{l}\text { Chinese Journal } \\
\text { Of Infection And } \\
\text { Chemotherapy }\end{array}$ & 278 & 0.92 & 0.4 & 0.112 \\
\hline
\end{tabular}

* SCImago Journal Rank: SCImago Journal Rank measures weighted citations received by the serial. Citation weighting depends on subject field and prestige (SJR) of the citing serial.

Figure 3 - Documents by authors.

Documents by author

Compare the document counts for up to 15 authors.

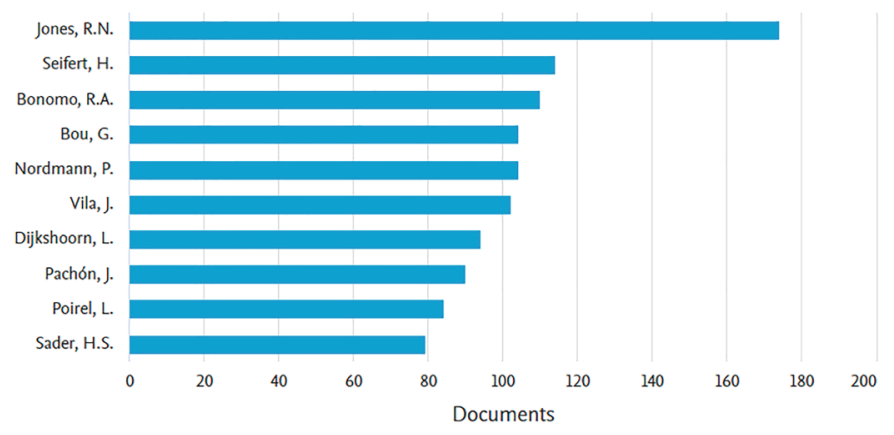

Table 4

The List of Most Cited Publications on Acinetobacter.

\begin{tabular}{|c|c|c|c|}
\hline Author, Year & Document title & Source & Cited by \\
\hline Magiorakos, 2012 & $\begin{array}{l}\text { Multidrug-resistant, extensively drug-resistant and pandrug-resistant bacteria: } \\
\text { An international expert proposal for interim standard definitions for acquired } \\
\text { resistance }\end{array}$ & $\begin{array}{l}\text { Clinical Microbiology and } \\
\text { Infection }\end{array}$ & 4988 \\
\hline Boucher,2009 & $\begin{array}{l}\text { Bad bugs, no drugs: No ESKAPE! An update from the Infectious Diseases Society } \\
\text { of America }\end{array}$ & Clinical Infectious Diseases & 3277 \\
\hline Wisplinghoff,2004 & $\begin{array}{l}\text { Nosocomial bloodstream infections in US hospitals: Analysis of 24,179 cases from } \\
\text { a prospective nationwide surveillance study }\end{array}$ & Clinical Infectious Diseases & 3111 \\
\hline Ventola,2015 & The antibiotic resistance crisis: Part 1: causes and threats & $\mathrm{P}$ and $\mathrm{T}$ & 1990 \\
\hline Vincent,2009 & $\begin{array}{l}\text { International study of the prevalence and outcomes of infection in intensive care } \\
\text { units }\end{array}$ & $\begin{array}{l}\text { JAMA - Journal of the } \\
\text { American Medical } \\
\text { Association }\end{array}$ & 1968 \\
\hline Gao,2013 & Human infection with a novel avian-origin & $\begin{array}{l}\text { New England Journal of } \\
\text { Medicine }\end{array}$ & 1776 \\
\hline Zhang,2015 & $\begin{array}{l}\text { Comprehensive evaluation of antibiotics emission and fate in the river basins of } \\
\text { China: Source analysis, multimedia modeling, and linkage to bacterial resistance }\end{array}$ & $\begin{array}{l}\text { Environmental Science and } \\
\text { Technology }\end{array}$ & 1649 \\
\hline Hammer,1999 & Antimicrobial activity of essential oils and other plant extracts & $\begin{array}{l}\text { Journal of Applied } \\
\text { Microbiology }\end{array}$ & 1636 \\
\hline Hidron,2008 & $\begin{array}{l}\text { Antimicrobial-resistant pathogens associated with healthcare-associated } \\
\text { infections: Annual summary of data reported to the National Healthcare Safety } \\
\text { Network at the Centers for Disease Control and Prevention, 2006-2007 }\end{array}$ & $\begin{array}{l}\text { Infection Control and } \\
\text { Hospital Epidemiology }\end{array}$ & 1525 \\
\hline Tacconelli,2018 & $\begin{array}{l}\text { Discovery, research, and development of new antibiotics: the WHO priority list of } \\
\text { antibiotic-resistant bacteria and tuberculosis }\end{array}$ & $\begin{array}{l}\text { The Lancet Infectious } \\
\text { Diseases }\end{array}$ & 1177 \\
\hline
\end{tabular}


The list of the top 10 journals according to the number of publications on Acinetobacter given in Table 3 and Figure 2. The journal with the highest number of articles on Acinetobacter is Antimicrobial Agents and Chemotherapy $(n=874)$.

Documents by authors are given in Figure 3. Ronald N Jones $(n=174)$ from USA and Harald Seifert $(n=114)$ from Germany were most productive authors on Acinetobacter releated publications (Figure 3).

Twelve of the articles were cited more than 1000 times, 38 of them more than 500 times, 155 of them more than 250 times, 1034 of them more than 100 times, among all the articles on Acinetobacter. The article written by Magiorakos was the most cited article $(\mathrm{n}=4988)$ on Acinetobacter

\section{Discussion}

Bibliometric analysis which is social science study area, has been started to use in medical area in recent years. As different researchers made this analysis on different medical topics, it became easier to give way to perspective for future studies [1116]. Pubmed, The Web of Science (WOS) and Scopus databases are mostly common databases mainly preferred in bibliometric analyses [11-16]. As Acinetobacter infections are common nosocomial pathogens all over the world and WHO reported it as an emerging pathogen we choose Acinetobacter keyword to highlight the importance of this topic and sought to give a bibliometric overview of the literature on Acinetobacter, by using Scopus database, which was used in previously published bibliometric studies. As a result of our study we detected the greatest number of articles published in the last 20 years period from 2000 to 2020 . But there was a rapid decrease in the number of articles by the year 2020. This status may be relevant to the pandemic.

In only similar study from Turkey on Acinetobacter topic. In this study, scientific publications on Acinetobacter bacteremia were analyzed by using the Web of Science (WOS) database. This study was limited to Acinetobacter bacteremia [11]. Our study had wider range on Acinetobacter. And similarly to our study, number of publications on Acinetobacter topic have been increasing and growing rapidly in the past decade. In this study the first article was written in the year 1985 [11]. In our study first article was written in the year 1965. The reason for this can be interpreted as the concept of Acinetobacter may have been understood after about 20 years to cause bacteremia.

In a study from Iran, a bibliometric analysis was conducted with using WOS database and co-citation analysis was made with the "TI" tag using Ravar PreMap, UCINET 6.528.0.0, and Netdraw 1.0.0.0 programs [12]. "Seifert, Harald" from Germany was found as the most productive author on Acinetobacter topic. In our study Ronald $\mathrm{N}$ Jones $(\mathrm{n}=174)$ from USA and Harald Seifert $(n=114)$ from Germany were the authors with most publications on Acinetobacter. The reason for the difference may be the narrower distribution of the WOS database. Magiorakos et al was the most cited author in our study. But in Danesh et al.'s [12] study "Seifert, Harald * Higgins, Paul G" were the top cited authors. This was attributed to the fact that we did not use a similar database with our study.

When the studies on Acinetobacter are examined in terms of the publication language, it is seen that the English is the mostly preferred language $[11,12]$. Our study findings were similar. The majority of the articles $(n=26862,89.31 \%)$ were written in English language. Chinese was the second mostly preferred language. This situation shows that English is dominant in the literature. This finding shows that Acinetobacter topic has globally importance.

As mostly previously studies [11-17], our study showed that the majority of articles from USA. This may due to research findings and large number of researchers in USA. But the top cited article was published by authors from European Centre for Disease Prevention and Control team [18]. This may be due to the fact that there is a reputable scientific community in the area of Infectious Diseases. In addition, the most cited 3 articles were published in the Clinical Microbiology and Infection journal, and this may due to the fact that this journal with a high impact factor and it is one of the most respected journals in the area of Infectious Diseases.

As a result, both the number of articles on Acinetobacter and the number of citations are quite high. Since Acinetobacter genus is one of the most important pathogens in hospital infections, it seems that researchers will continue to work on this subject.

\section{Limitations of the study}

In this study single database used for research. So, we cannot say that the findings obtained in the research we conducted in a single database represent the total literature on Acinetobacter. As bibliometric databases only indexes the academic publications that it covers. International citation indexes include only academic publications indexed in the used database. So regional literature which don't listed in international citation indexes don't have international visibility. This is the second limitation of our study.

Disclosures: There is no conflict of interest for all authors.

\section{Acknowledgements: None.}

\author{
Funding: None.
}

\section{References}

1. Esen B, Gözalan A. Acinetobacter calcoaceticus-Acinetobacter baumannii complex (ABC) ve Yeni Türleri. Kocatepe Tip Dergisi. 2020; 21(2):211-6. https://doi.org/10.18229/kocatepetip.545268

2. Yıldız E, Tokur M, Yıldız E, Arık Ö, Alkan Çeviker S. Yoğun Bakım Hastalarında Gelişen Sağlık Hizmeti İle İlişkili Acinetobacter Baumanii Bakteriyemilerinin Retrospektif Değerlendirilmesi. J Biotechinol \& Strategic Health Res. 2020; 4(3):283-91. https://doi. org/10.34084/bshr.814451

3. Irvem A. Colistin-daptomycin, colistin-linezolid, colistin-vancomycin combination effects on colistin in multi-resistant acinetobacter baumannii strains. Medical Science and Discovery. 2018; 5(2):124-9. https://doi.org/10.17546/msd.391234

4. Aydın M, Azak E, Bilgin H, Menekse S, Asan A, Mert HTE, et al. Changes in antimicrobial resistance and outcomes of health careassociated infections. Eur J Clin Microbiol Infect Dis. 2021. doi: 10.1007/s10096-020-04140-y.

5. Kızılarslanoğlu MC, Ergönül Ö, Çetinkaya-Şardan Y, Akova M. Acinetobacter baumannii infection and colonization in the intensive care unit: risk factors, transmission routes, and transmission dynamics. Klimik Derg. 2018; 31(1):20-9. https://doi.org/10.5152/kd.2018.07 
6. Wong D, Nielsen TB, Bonomo RA, Pantapalangkoor P, Luna B, Spellberg B. Clinical and Pathophysiological Overview of Acinetobacter Infections: a Century of Challenges. Clin Microbiol Rev. 2017; 30(1):409- 47. doi:http://dx.doi.org/10.1128/CMR.00058-16

7. Kireçci E, Kireçci M, Aksu M. Investigation of the Antibiotic Susceptibility of Acinetobacter baumannii Strains Isolated from Clinical Samples. Türk Mikrobiyol Cem Derg. 2014; 44(2):65-9. doi:10.5222/TMCD.2014.065.

8. World Health Organization. Global priority list of antibiotic-resistant bacteria to guide research, discovery, and development of new antibiotics. Available at: http://www.who. int/medicines/publications/WHO-PPL-Short_Summary_25Feb ET_NM_WHO.pdf. [Accessed July 10, 2021].

9. Temel A, Eraç B. Küresel bir tehdit: Acinetobacter baumannii, antimikrobiyal dirençte güncel durum ve alternatif tedavi yaklaşımları Turk Hij Den Biyol Derg. 2020; 77(3):367-78. https://doi.org/10.5505/TurkHijyen.2019.04764

10. Arıca R, Çorbacı A. Müşterilerin Ortak Üreticilik Rolünü Konu Edinen Araştırmaların İncelenmesi: Scopus Veri Tabanında Taranan Turizm ve Otelcilik Dergilerinin Bibliyometrik Açıdan Değerlendirilmesi. Turizm Akademik Dergisi. 2019; 6(1):263-76.

11. Alkan S, Dindar Demiray EK, Yıldız E, Özlü C. Analysis of Scientific Publications on Acinetobacter bacteremia in Web of Science. Infect Dis Clin Microbiol. 2021; 1:39-44. https://doi.org/10.36519/idcm.2021.37

12. Danesh F, GhaviDel S, Emami M. Acinetobacter Baumannii: Researchers' Scientific Cooperation Network in Three Decades. Iran J Med Microbiol. 2020; 14(3):252-69. https://doi.org/10.30699/ijmm.14.3.252

13. Öntürk H, Dindar Demiray EK, Alkan S. Network analysis of nursing publications in the COVID 19 era. J Clin Med Kaz. 2021; 18(4):27-31. https://doi.org/10.23950/jcmk/11037

14. Özlü C. Scopus Veri Tabanına Dayalı Bibliyometrik Değerlendirme: Miyelodisplastik Sendrom Konulu Yayınların Global Analizi ve Türkiye Kaynaklı Yayınların Değerlendirilmesi. Journal of Biotechnology and Strategic Health Research. 2021; 5(2):125-131. https://doi.org/10.34084/bshr.948974

15. Samanci Y, Samanci B, Sahin E. Bibliometric analysis of the top-cited articles on idiopathic intracranial hypertension. Neurol India. 2019; 67(1):78-84. https://doi.org/10.4103/0028-3886.253969

16. Lepard JR, Walters BC. A Bibliometric Analysis of Neurosurgical Practice Guidelines. Neurosurgery. 2020; 86(5):605-614. https://doi. org/10.1093/neuros/nyz240

17. Yağan Ö, Şenel E, Kayır S. Mushroom toxicity in academic literature: Holistic analysis of the global publications on mushroom poisoning between 1975 and 2019. J Clin Med Kaz. 2020; 6(60):48-52. https://doi.org/10.23950/jcmk/9256

18. Magiorakos A-P, Srinivasan A, Carey RB, Carmeli Y, Falagas ME, Giske CG, et al. Multidrug-resistant, extensively drug-resistant and pandrug-resistant bacteria: an international expert proposal for interim standard definitions for acquired resistance. Clin Microbiol Infect. 2012; 18(3):268-281. https://doi.org/10.1111/j.1469-0691.2011.03570.x 